\title{
Quetiapine Fumarate Extended-release Tablet Formulation Design Using Artificial Neural Networks
}

\author{
Ketiapin Fumarat Etkin Maddesini İçeren Uzatılmış Salımlı Tablet \\ Formülasyonlarının Yapay Sinir Ağları ile Tasarımı
}

\author{
Esher ÖZÇELIK'1 Burcu MESUT¹, Buket AKSU², Yıldız ÖZSOY* \\ IIstanbul University, Faculty of Pharmacy, Department of Pharmaceutical Technology, İstanbul, Turkey \\ ${ }^{2}$ Istanbul Kemerburgaz University, Faculty of Pharmacy, Department of Pharmaceutical Technology, İstanbul, Turkey
}

\section{ABSTRACT}

Objectives: This design study was implemented within the scope of the quality by design approach, which included the "International Conference on Harmonization" guidelines. We evaluated the quality of a modified-release tablet formulation of quetiapine fumarate, which was designed using artificial neural networks (ANN), and determined a new formulation that was similar to the reference product.

Materials and Methods: Twelve different formulations were produced and tested. The reference product's results and our experimental results were used as outputs for the training of the ANN programs of Intelligensys Ltd.

Results: Dissolution tests were performed with the new formulation (F13) suggested by the INForm V.4 ANN program in three different pHs of the gastrointestinal system. The compliance of this formulation was confirmed by comparing the results with an $\mathrm{f} 2$ similarity test.

Conclusion: Use of these programs supports research and development processes with multiple evaluation methods and alternative formulations may be determined faster and at lower cost.

Key words: Quetiapine fumarate, quality by design, artificial neural networks, neuro-fuzzy logic, extended-release tablets, wet granulation

öz

Amaç: Bu tasarım çalışması “International Conference on Harmonization” rehberleri kapsamındaki tasarımda kalite yaklaşımı çerçevesinde uygulanmıştır. Yapay sinir ağları (ANN) kullanılarak ketiapin fumaratın değiștirilmiş salımlı tablet formülasyonunun kalitesi değerlendirilmiş ve referans ürüne benzer olan yeni bir formülasyon tespit edilmiștir.

Gereç ve Yöntemler: On iki farklı formül üretilmiş ve test edilmiştir. Referans ürünün analiz sonuçları ve deneysel sonuçlarımız çıktı olarak Intelligensys Ltd. şirketine ait programlarında ANN'nin eğitimi için kullanılmıştır.

Bulgular: INForm V.4 ANN programı tarafından önerilen yeni bir formülasyon (F13) ile gastrointestinal sistemdeki üç farklı pH da çözünme testleri yapılmıştır. Bu formülasyonun uygunluğu da f2 benzerlik testi sonuçları karşılaştırılarak doğrulanmıştır.

Sonuç: Bu programların kullanılması, çoklu değerlendirme yöntemleri ve daha düşük maliyetle Ar-Ge süreçlerini desteklemekte ve alternatif formülasyonlar daha hızlı tespit edilebilmektedir.

Anahtar kelimeler: Ketiapin fumarat, tasarımda kalite, yapay sinir ağları, bulanık mantık, uzatıımış salım tabletler, yaş granülasyon

*Correspondence: E-mail:yozsoy@istanbul.edu.tr, Phone: +90 2124400272 ORCID-ID: orcid.org/0000-0002-9110-3704

Received: 14.10.2016, Accepted: 09.03.2017

-Turk J Pharm Sci, Published by Galenos Publishing House. 


\section{INTRODUCTION}

Quetiapine fumarate, a Biopharmaceutics Classification System class 2 drug, has been used in the treatment of schizophrenia. Its conventional and extended-release (ER) preparations are available on the market. Its ER formulations ensure safe, clinically effective treatment within accepted therapeutic intervals due to the decreased adverse effects and increased patient treatment adherence.'

ER formulations of quetiapine fumarate are prepared as membrane or matrix delivery systems. Mostly hydrophilic polymers are used in the formulation of ER systems. In particular, semi-synthetic cellulose derivatives, acrylic acid derivatives (carbomers), and natural polysaccharides are preferred. ${ }^{1-4}$

Carbopol 974P, an acrylic acid derivative, is used as a binding agent, which increases viscosity, film coating, and acts as a suspension agent material due to its capability of forming a gel at high viscosity. ${ }^{5}$ In addition, it controls the release rate of the drug through hydration and swelling mechanisms. Xanthan gum, a microbiologic polysaccharide, is produced by Xsanthomonas campestris with pure culture fermentation. It is also widely used as a stabilizer, suspension agent, viscosity increaser ${ }^{6}$, and as a matrix agent in ER formulations ${ }^{7}$ due to its capability to form a strong matrix structure.

The wet granulation method for the preparation of ER tablets is a common process in the pharmaceutical industry. ${ }^{8}$ Decreasing the time and cost of industrial scale production are the most important parameters in the development of ER tablets. ${ }^{9}$ In recent years, neural networks, fuzzy-logic programs, and multiple evaluation techniques have been used for the optimization of pharmaceutical formulations due to their advantages over classic formulation development strategies, such as being time saving and having lower cost. In addition, efficiency and quality are other important parameters in pharmaceutical development and production. There are some tools for these objectives such as faster analysis of data, efficient use of incomplete data banks, training of newly developed networks, exploring independent design areas away from complicated designs, finding the most useful choice, establishing restrictions in optimization, and producing useful norms. ${ }^{10}$

An artificial neural network (ANN) is an artificial intelligence tool that identifies arbitrary non-linear multi-parametric distinguishing functions directly from dependent and independent complex variables. Thus, it can separate signals and noise from experimental data. ${ }^{11,12}$ These programs evaluate dissolution profiles ${ }^{13}$ and take into account the physicochemical properties of products, such as friability and disintegration, and other consequential parameters that affect the release rate of drugs (particle size, type and amount of polymer, granulation technique, compression force, amount and type of lubricant). ${ }^{14}$

FormRules V3.32, a neural network-fuzzy logic program, INForm V.4 ANN, and V.4 gene expression programing (GEP) programs were used in the research and development studies..$^{15}$ FormRules is a hybrid technology that is a very effective tool to obtain understandable rules from complex and non-linear data. ${ }^{16}$
The INForm programs use neural network-fuzzy logic and can perform optimization. Optimization is a mathematic method that searches for an "optimum" and most advantageous solutions to solve problems. As for INForm V.4 GEP, it is based on genetic algorithms, searching for the best holistic solutions according to the principle of 'survival of the fittest' in the multidimensional search space. ${ }^{17}$

Quality by Design (QbD) is included in the International Council for Harmonisation of Technical Requirements for Registration of Pharmaceuticals for Human Use (ICH) Q8 guideline and, by enabling the use of data observed throughout the life cycle, it provides more scientific data regarding the product quality and to critical process knowledge. ${ }^{18}$ In the pharmaceutical industry, $Q b D$ is a very important contributor and emphasizes comprehension of process control, and quality products may be achieved more quickly with a systematic approach. ${ }^{19-23}$

In this study, ER formulations of quetiapine fumarate were prepared with xanthan gum or Carbopol 974P as matrix agents at their different ratios and an optimum formulation was developed that would be similar to the reference drug (Seroquel $200 \mathrm{mg} \mathrm{XR} \mathrm{tablet,} \mathrm{AstraZeneca)} \mathrm{in} \mathrm{the} \mathrm{market.} \mathrm{In}$ this context, the effect of granule size of bulk was investigated on the dissolution profiles of drug from formulated ER tablets. Critical quality characteristics and process parameter inputs were determined as polymer type-concentrations and sieving mesh sizes of dried granules, respectively. Then, a design study was conducted to follow the changes of the obtained outputs of the formulations and evaluated using FormRules V3.32, INForm programs.

\section{EXPERIMENTAL}

\section{Equipment}

The equipment used included the following: tablet press machine (Rimek-Minipress-II, Karnavati-India), dissolution test apparatus (Distek Syringe Pump-Evolution 4300 Dissolution Sampler - USA), friability machine (Caleva FT-15, UK), hardness test apparatus (Caleva THT-15, UK), magnetic stirrer (Hei-standard, Heidolph MR), pH meter (Seven Easy, Mettler Toledo-Switzerland), HPLC (Waters e2695 PDA detector, Waters-USA), ultrasonic bath (RK $1028 \mathrm{CH}$, Bandelin Sonorex Super), wet stoker (Mettler LP16, Mettler), oven (Nuve) KD 200, balance (Mettler PM100, Mettler-Switzerland), mechanical stirrer (Stirrer LH, Velp Scientifica), FormRules V3.32, INForm V.4 ANN, and INForm V.4 GEP softwares (INtelligent Ltd-UK).

\section{Ingredients}

Quetiapine (fumarate salt) (Aurobindo Pharma Limited, Unit-XI- India), MCC 101 (FMC Biopolymer, Newark, USA), lactose monohydrate (DMV, Netherlands), sodium citrate (Merck, Germany), Carbopol 974P (Lubrizol, USA), xanthan gum (JUNGBUNZLAUER, Switzerland), Mg stearate ( $F A C l$, Genoa, Italy) were pharma grade and all other chemicals were analytical grade.

\section{Data set}

In this study, polymer type, polymer concentrations, and sieving mesh size parameters were described as independent variables 
(inputs); tablet weight, tablet hardness, friability, assay and dissolution percentage (\%) at all of the time points used in the dissolution tests (30 min and 1, 2, 3, 4, 5, 6, 8, 10, 12, 14, 16, 18, 20,22 , and 24 hours) were described as dependent variables (outputs). Therefore, two different polymer types (xanthan gum and Carbopol 974P), three different concentrations for each polymer [according to the preliminary study findings for xanthan gum; $16 \%, 24.5 \%$, and $31 \%$ (w/w), for Carbopol 974P; 10\%, 23\%, and $50 \%(w / w)$ ], and two different sieving mesh sizes ( 0.8 and $1.4 \mathrm{~mm}$ ) for dry granules were suggested.

A systematic scientific approach was applied to control tablet production variables in the process design. For this purpose, a study design was formed by determining the critical parameters for the formulation within the framework of the $\mathrm{QbD}$ approach. These variables were also formed as the critical quality attributes. The main goal of our study was to be able to understand the possible effects of these parameters on the release profiles of ER quetiapine fumarate tablets. Then, training of the FormRules V.3.32 and INForm programs was conducted with the observed test results. The results showed that formulation F1 was the most similar formulation to the reference product chosen by the programs. In addition, formulation F13 was suggested as a new formula after optimization from INForm programs. Afterwards, F1 and F13 dissolution profiles were tested at three different $\mathrm{pH}$ values, as proposed by the $\mathrm{ICH}$ Q6 guidelines $(\mathrm{pH} 1.2,4.5$, and 6.8).

The dissolution profiles of $\mathrm{F} 1$ and $\mathrm{F} 13$ were compared with the reference product to determine whether it adhered to the compliance criteria. ${ }^{24}$ The critical quality and process parameters (inputs) and quality target product profiles (outputs) in the process design are shown in Table 1, and the visualizations of the interactions between these properties are shown with their positions in a fishbone diagram in Figure 1.

\section{Tablet formulation and manufacturing}

All tablet formulations containing $230 \mathrm{mg}$ of quetiapine fumarate were prepared with the wet granulation method (Table 2). A flow diagram of the production method is shown in Figure 2. In brief, quetiapine fumarate, lactose monohydrate, sodium citrate, microcrystalline cellulose 101, and the polymer (xanthan gum or Carbopol 974P) were weighed and sieved as the internal phase and mixed in a mechanical mixer for $10 \mathrm{~min}$. Granulation was

\section{Table 1. Dependent and independent variables of formulations in} process design

\begin{tabular}{ll}
$\begin{array}{l}\text { Critical quality and proses parameters } \\
\text { (Inputs) }\end{array}$ & $\begin{array}{l}\text { Quality target product } \\
\text { profile properties (Outputs) }\end{array}$ \\
\hline $\begin{array}{l}\text { Polymer type } \\
\text { (Xanthan gum or Carbopol 974P) }\end{array}$ & $\begin{array}{l}\text { Tablet weight (mg) } \\
\text { Hardness (n) }\end{array}$ \\
Polymer concentration & Friability (\%) \\
Xanthan gum: (16-24.5-31\%; w/w) & Assay (\%) \\
Carbopol 974P: (10-23-50\%; w/w) & Dissolution \\
Sieve size & Amount of dissolved (\%) in \\
(0.8 or $1.4 \mathrm{~mm})$ & all time points \\
& $(30$ min, 1, 2, 3, 4, 5, 6, 8, 10, \\
& $12,14,16,18,20,22,24 \mathrm{~h})$ \\
\hline
\end{tabular}

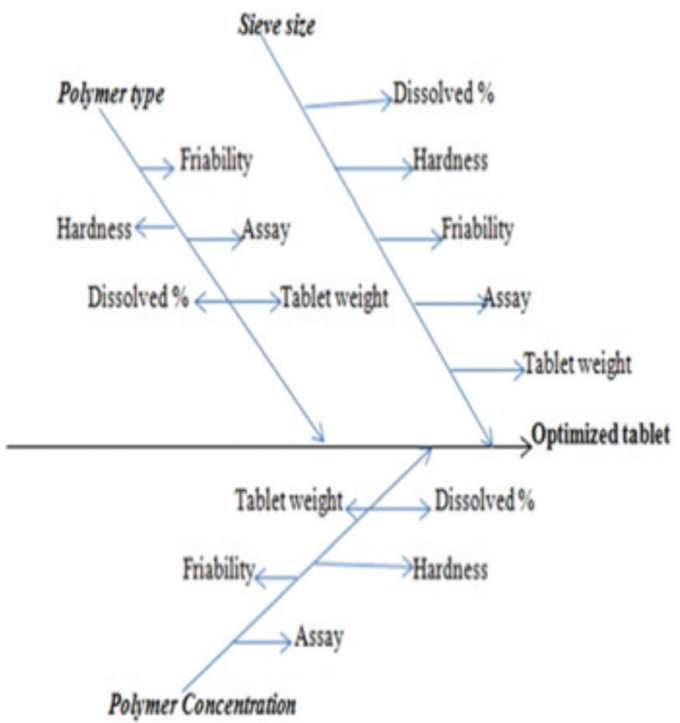

Figure 1. Critical characteristics of extended-release tablet formulation in fishbone model

\section{Table 2. Unit formula ingredients of tablets}

\begin{tabular}{|c|c|c|c|c|c|c|}
\hline Ingredients (mg) & $\begin{array}{l}\mathrm{F}^{*} \\
\mathrm{~F} 2^{* *}\end{array}$ & $\begin{array}{l}\mathrm{F}^{*} \\
\mathrm{F4}^{* *}\end{array}$ & $\begin{array}{l}\mathrm{F}^{*} \\
\mathrm{~F}^{* *}\end{array}$ & $\begin{array}{l}\mathrm{F} 7^{*} \\
\mathrm{~F} 8^{* \star}\end{array}$ & $\begin{array}{l}\mathrm{F}^{*} \\
\text { F10** }\end{array}$ & $\begin{array}{l}\mathrm{F} 11^{*} \\
\mathrm{~F} 12^{* *}\end{array}$ \\
\hline $\begin{array}{l}\text { Quetiapine fumarate } \\
\text { (200.0 mg Quetiapine equivalent) }\end{array}$ & 230.0 & 230.0 & 230.0 & 230.0 & 230.0 & 230.0 \\
\hline Microcrystalline cellulose 101 & 100.0 & 100.0 & 100.0 & 100.0 & 100.0 & 100.0 \\
\hline Lactose monohydrate & 52.63 & 52.63 & 52.63 & 52.63 & 52.63 & 52.63 \\
\hline Carbopol 974P & - & - & - & 53.05 & 143.2 & 477.48 \\
\hline Xanthan gum & 93.0 & 155.0 & 217.0 & - & - & - \\
\hline Mg stearate & 6.0 & 6.0 & 6.0 & 6.0 & 6.0 & 6.0 \\
\hline Tablet weight & 570.49 & 632.49 & 694.49 & 530.54 & 620.69 & 954.96 \\
\hline
\end{tabular}

${ }^{*} \mathrm{~F} 1, \mathrm{~F} 3, \mathrm{~F} 5, \mathrm{~F} 7, \mathrm{~F} 9$, and F11 were sieved through $0.8 \mathrm{~mm}$ mesh screen; **F2, F4, F6, F8, F10, and F12 were sieved through $1.4 \mathrm{~mm}$ mesh screen 
achieved by slowly adding distilled water to the dry mixture; when the granules reached the desired consistency, they were sieved with a 4-mm mesh screen. The wet granules were dried in an oven at $45^{\circ} \mathrm{C}$ and then divided into two parts; one part was sieved through a $0.8 \mathrm{~mm}$ mesh screen and the other was sieved through a $1.4 \mathrm{~mm}$ mesh screen. Magnesium stearate was sieved and added to the granules as the outer phase. The product was mixed in a mechanical mixer for $5 \mathrm{~min}$ and tablets were compressed using a tablet compressor (Karnavati Tablet Compression Machine, India).

\section{Tests for prepared tablets}

\section{Weight variation}

For all formulations, 10 tablets were weighed one-by-one on a precision scale (Mettler-Switzerland), and average weight, standard deviation, and relative standard deviation values were calculated.

\section{Determination of hardness}

Ten tablets were taken from all formulations. Tablet hardness was measured using a hardness testing instrument (Caleva, UK). Average hardness, standard deviation, and relative standard deviation values were calculated.

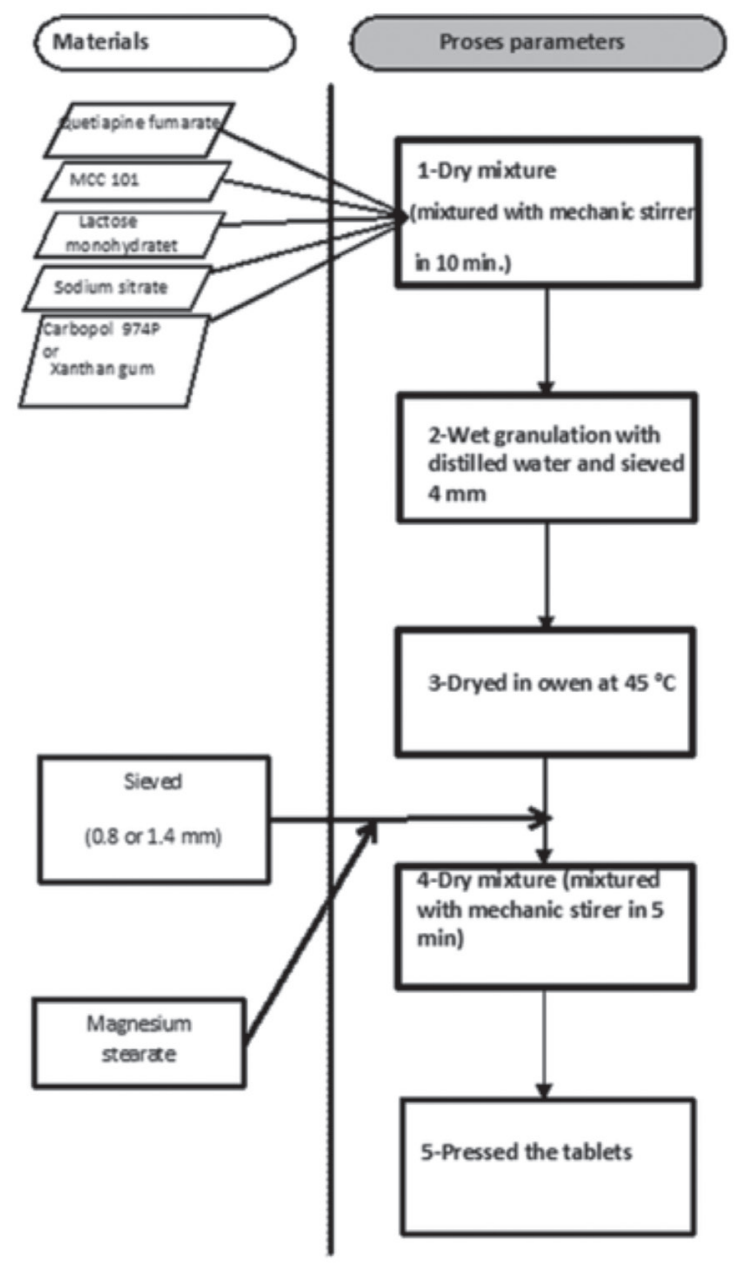

\section{Friability test}

From all formulations, 10 tablets were weighed and placed in a friability tester (Caleva, UK); the instrument was run, a test was conducted at $25 \mathrm{rpm}$ for $4 \mathrm{~min}$, and the tablets were weighed after the procedure. Percentage weight loss was calculated according to Equation $1^{25}$ :

$F(\%)=\frac{(W i-W f)}{W_{i}} \times 100 \quad$ (Equation 1)

Where,

$W i=$ initial weight of tablets

$W f=$ weight after friabilityv

\section{Assay}

HPLC (Waters) was used for quetiapine fumarate analysis. ${ }^{26}$ Method parameters are summarized as follows;

Detector: PDA

Mobile phase: $\mathrm{pH} 6.5$ phosphate buffer-acetonitrile (60:40; v/v) Column: Cromasil 100, $C_{18}(250 \times 4.6$ mm), $5 \mu \mathrm{m}$

Wavelength: $225 \mathrm{~nm}$

Flow rate: $1.5 \mathrm{~mL} / \mathrm{min}$

Retention time: 4 min

The determination of active substance amount in ER tablets containing $230 \mathrm{mg}$ of quetiapine fumarate and dissolution rate test method validation (accuracy, precision, specificity, linearity, range, detection limit, quantitation limit, robustness, system suitability testing) were performed according to the $\mathrm{ICH}$ Q2 guidelines. ${ }^{27}$

\section{Dissolution tests}

For the similarity between the developed ER formulations of quetiapine fumarate and reference product, a dissolution test was performed in the medium $(0.1 \mathrm{~N} \mathrm{HCl}, 900 \mathrm{~mL})$ registered in the literature. USP apparatus II with the paddle method was used for this test at $37^{\circ} \mathrm{C} \pm 0.5$ at $50 \mathrm{rpm} .{ }^{28}$ The experiments were performed six times. The analysis of samples, which were taken from the dissolution medium at the determined time intervals (at the end of 30 min and 1, 2, 3, 4, 5, 6, 8, 10, 12, 14, 16, $18,20,22$, and 24 hours) was performed and fresh dissolution medium was added. Dissolution tests were also conducted under the same conditions using different dissolution media including buffered solutions at $\mathrm{pH} 1.2, \mathrm{pH} 4.5$, and $\mathrm{pH} 6.8$.

\section{Evaluation of dissolution data}

The similarity of dissolution profiles of ER quetiapine fumarate tablet formulations and that of the reference ER product were determined using the $\mathrm{f} 2$ test (similarity factor) ${ }^{29}$ given in Equation 2:

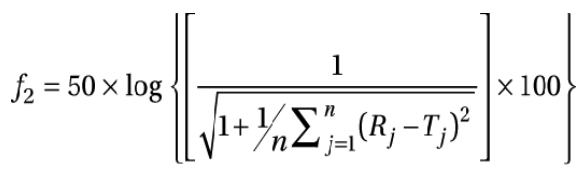

(Equation 2)

Figure 2. Process flow chart of extended-release tablets prepared 
Where $R j$ and $T j$ are the cumulative percentages dissolved at each of the selected " $n$ " time points of the reference and test product, respectively. For similarity of the formulations, this factor should be between 50 and 100 .

\section{Software tools}

Commercial artificial intelligence software tools were used to interrogate the production data generated in the studies.

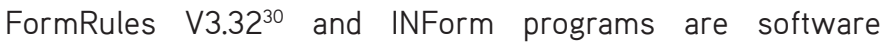
packages developed by Intelligensys Ltd., UK.

\section{RESULTS}

\section{Analytical validation results}

Linearity concentrations range between $10-120 \%$. The limit of detection value was $5.0 \mathrm{mg} / \mathrm{mL}$ and the limit of quantification value was $16.667 \mathrm{mg} / \mathrm{mL}$. The other validation procedure results are shown in Table 3.

\section{Physical tests results}

Physical tests of the formulations were performed. The average diameter of the tablets was between 17.88-17.99 mm for formulations composed of both polymers, and the thickness values were between 5.36-6.01 $\mathrm{mm}$ for tablets prepared with xanthan gum, and between 5.21-8.20 mm for the Carbopol 974P series. The assay results of the tablets were between 98.07$102.00 \%$. Other physical tests results are shown in Table 4. All parameters were within the Pharmacopoeia limits. ${ }^{31,32}$

\section{Dissolution tests results}

The dissolution profiles of all formulations were compared with that of the reference product. All dissolution studies were performed in the best-dissolved medium of quetiapine fumarate for 24 hours ( $\mathrm{pH}$ 1.2) (Figure 3). The similarity factor (f2) values for all formulations were calculated and are shown as a histogram in Figure 4. The $\mathrm{f} 2$ similarity values of formulations coded with F1, F2, F3, F4, F6, and F12 were calculated as 69, 52, $63,68,68$, and 55, respectively. The formulations coded as F1, F4, and F6 were highly similar to the reference product.

\section{FormRules program results}

Training of programs was conducted using the physical and chemical test results of all formulations, and the results were evaluated. The $r^{2}$ value was 0.99 for the average weight data and the polymer concentration was the dependent variable. Polymer concentrations and hardness values can influence each other moderately, as such, the dependent variables and models also have influence.
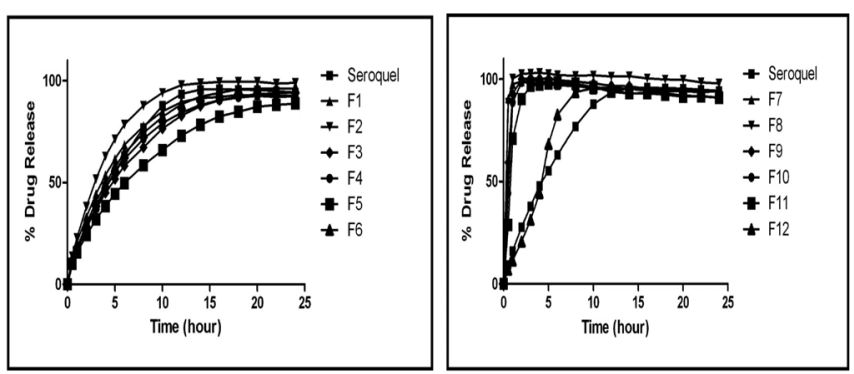

Figure 3. Dissolution profiles of all formulations developed and reference product at $\mathrm{pH} 1.2(\mathrm{n}=6)$

\section{Table 3. Results of analytical validation procedure}

$$
\text { Validation characteristics }
$$

Specificity

System repeatability

\begin{tabular}{|c|c|c|c|}
\hline \multicolumn{2}{|l|}{ Linearity } & \multicolumn{2}{|l|}{$R^{2}: 1$} \\
\hline \multirow{3}{*}{\multicolumn{2}{|c|}{ Range }} & \multirow{3}{*}{\multicolumn{2}{|c|}{$\begin{array}{l}\text { RSD \%: } 1.72(10 \%) \\
\text { RSD \%: } 0.65 \text { (120\%) } \\
\text { No deviation observed in the specified range }\end{array}$}} \\
\hline & & & \\
\hline & & & \\
\hline \multirow[t]{2}{*}{ Accuracy } & & Xanthan gum & Carbopol 974P \\
\hline & & Yield \%: 98.11-100.27-98.93 & Yield \%: 99.71-100-100.75 \\
\hline \multicolumn{2}{|l|}{ Precision } & RSD \%: $1.918-91.50 \%$ & RSD \%: $1.921-94.47 \%$ \\
\hline \multirow{2}{*}{\multicolumn{2}{|c|}{ Intermediate precision }} & RSD \%: 0.748 & RSD \%: 1.838 \\
\hline & & Contrast \%: 3.83 & Contrast \%: 3.46 \\
\hline \multirow[t]{4}{*}{ Robustness } & Mobil phase flow rate & $1.35 \mathrm{~mL} / \mathrm{min}$ : Contrast \%: 1.88 & $1.35 \mathrm{~mL} / \mathrm{min}:$ Contrast \%: 0.19 \\
\hline & & $1.65 \mathrm{~mL} / \mathrm{min}:$ Contrast \%: 2.03 & $1.65 \mathrm{~mL} / \mathrm{min}$ : Contrast \%: 4.59 \\
\hline & Column temperature & $20^{\circ} \mathrm{C}$ : Contrast \%: 0.25 & $20^{\circ} \mathrm{C}$ : Contrast \%: 0.81 \\
\hline & & $30^{\circ} \mathrm{C}$ : Contrast \%: 0.82 & $30^{\circ} \mathrm{C}$ : Contrast \%: 0.52 \\
\hline
\end{tabular}

Results

There was no peak observed at the time of active substance retention time from the solvent or placebo.

RSD \%: 1.989 
Table 4. Tablet weight, hardness, friability (\%) results of all formulations

\begin{tabular}{llllll} 
Formula & \multicolumn{2}{c}{ Tablet weight } & \multicolumn{2}{c}{ Hardness } & \multirow{2}{*}{$\begin{array}{c}\text { Friability } \\
(\%)\end{array}$} \\
\cline { 1 - 4 } F1 & $(\mathrm{mg})$ & $\mathrm{SD}(+)$ & $(\mathrm{n})$ & $\mathrm{SD}(+)$ & 0.030 \\
\hline F2 & 560.20 & 2.05 & 187.00 & 21.02 & 0.140 \\
\hline F3 & 571.58 & 2.22 & 133.10 & 16.44 & 0.030 \\
\hline F4 & 634.40 & 0.81 & 207.00 & 31.41 & 0.42 \\
\hline F5 & 693.20 & 0.76 & 227.00 & 14.68 & 0.050 \\
\hline F6 & 693.35 & 4.81 & 169.00 & 28.07 & 0.068 \\
\hline F7 & 531.41 & 5.13 & 131.30 & 37.86 & 0.190 \\
\hline F8 & 534.79 & 3.32 & 157.90 & 44.07 & 0.260 \\
\hline F9 & 623.95 & 3.32 & 242.50 & 19.63 & 0.063 \\
\hline F10 & 622.78 & 3.33 & 254.70 & 4.24 & 0.061 \\
\hline F11 & 960.64 & 3.12 & 255.40 & 0.70 & 0.120 \\
\hline F12 & 962.32 & 1.56 & 256.30 & 2.16 & 0.120 \\
\hline
\end{tabular}

SD: Standard deviation

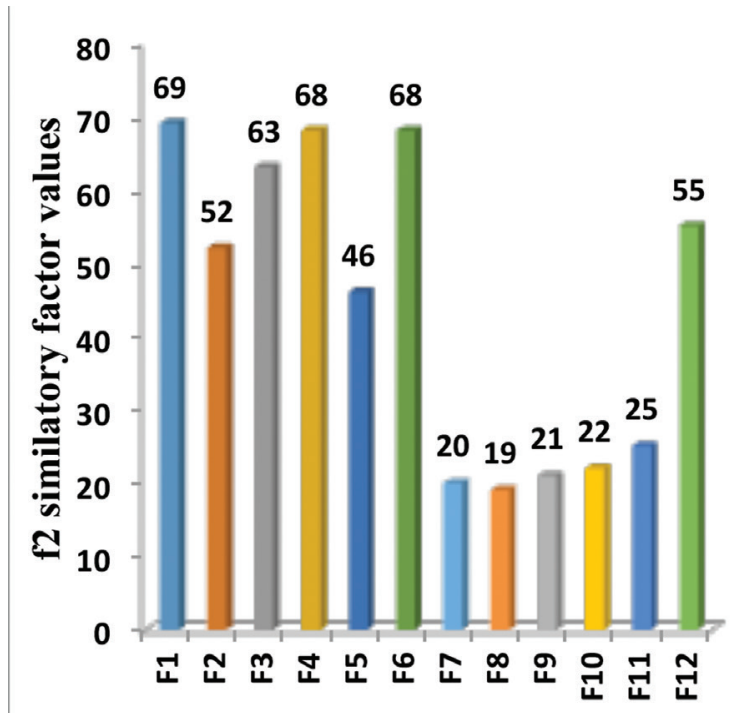

\section{Formula}

Figure 4. Similarity factor ( $f 2$ ) values of all tablet formulations

The dependent variables of polymers are highly important for the dissolution rate of drugs. If the polymer type and concentration change, the drug dissolution profiles would also change. When Carbopol 974P was used, the dissolution percentage of drug was high, and the dissolution behavior of drug was not affected due to the particle size. ${ }^{33}$ When xanthan gum was used as the polymer, the dissolution percentage of drug was decreased. ${ }^{34,35}$ The change in drug release by polymer type observed in this study complies with the literature. The release of active substance from hydrophilic matrix tablets is related to a product's own behavior, and the typical characteristics of the drug together with the properties of the polymer, i.e., molecular weight, hydrophilicity, and degree of cross-linking. ${ }^{36}$ An inverse proportionality was detected between polymer concentration and dissolution percent of drug. Therefore, it was suggested that in vitro release behavior of drug was related to polymer concentration. Increased polymer concentration led to decreased diffusion of drug in the dissolution medium. Thus, the types and concentrations of polymers are crucial factors that affect dissolution of drugs. ${ }^{37}$

The similarity values were obtained using the FormRules program. Formulation F1 was found as the most similar to the reference product (100\%). This formulation also showed the highest similarity to the reference product (69\%) in terms of $\mathrm{f} 2$ similarity factor when the dissolution study was performed at $\mathrm{pH} 1.2$.

\section{INForm program results}

All results were also evaluated using the INForm programs. It was observed that the $r^{2}$ values ranged from 74.31 to 99.97 for weight, hardness, friability (\%), assay, and dissolution rates (\%) of tablets.

When the $r^{2}$ values were high, the model was well-built, and the program was conditioned. F1 was the most similar formulation to the reference product according to the INForm data.

\section{DISCUSSION}

ER oral tablets are required to meet similar behaviors in the gastrointestinal tract in which physiologic fluids are at different $\mathrm{pH}$ values. Thus, in vitro dissolution studies are needed to be performed at three different $\mathrm{pH}$ values that mimic in vivo conditions. Following the evaluation of all dissolution studies and assessment of program data, formulation F1 was determined as the most similar to the reference product. The dissolution tests were performed in dissolution media at $\mathrm{pH} 1.2,4.5$, and 6.8. Although formulation $\mathrm{F} 1$ satisfied the $\mathrm{ICH}$ guideline ${ }^{24}$ limits at $\mathrm{pH} 1.2$ and $\mathrm{pH} 6.8$ (f2 values were 69 and 95, respectively), the $\mathrm{f} 2$ value for this formulation was calculated as 23 in $\mathrm{pH}$ 4.5 dissolution medium. Therefore, the formulation was not assessed as similar to the reference product.

Furthermore, the INForm programs recommended a new optimized formulation, which had the highest similarity to the reference product. However, the two formulations were very similar in terms of drug dissolution rates. Therefore, we chose the formula recommended by the ANN program, and the tablets were prepared according to this proposed formula (F13) in which xanthan gum was used as the polymer matrix agent $[20.35 \%(\mathrm{w} / \mathrm{w})]$ and the granule size was $1.0 \mathrm{~mm}$.

To prove the similarity of the F13 formulation to the reference product, in vitro dissolution studies were performed using the dissolution method as explained above. The dissolution profiles of drug performed at three different $\mathrm{pH}$ values are shown in Figures 5-7. F2 similarity values of formulation $\mathrm{F} 13$ at $\mathrm{pH} 1.2$, 4.5 , and 6.8 were calculated as 76,50 , and 62 , respectively.

The formulation selected by the FormRules (F1) and the INForm programs (F1) that showed the most similarity to the reference product did not show the expected performance in in vitro 


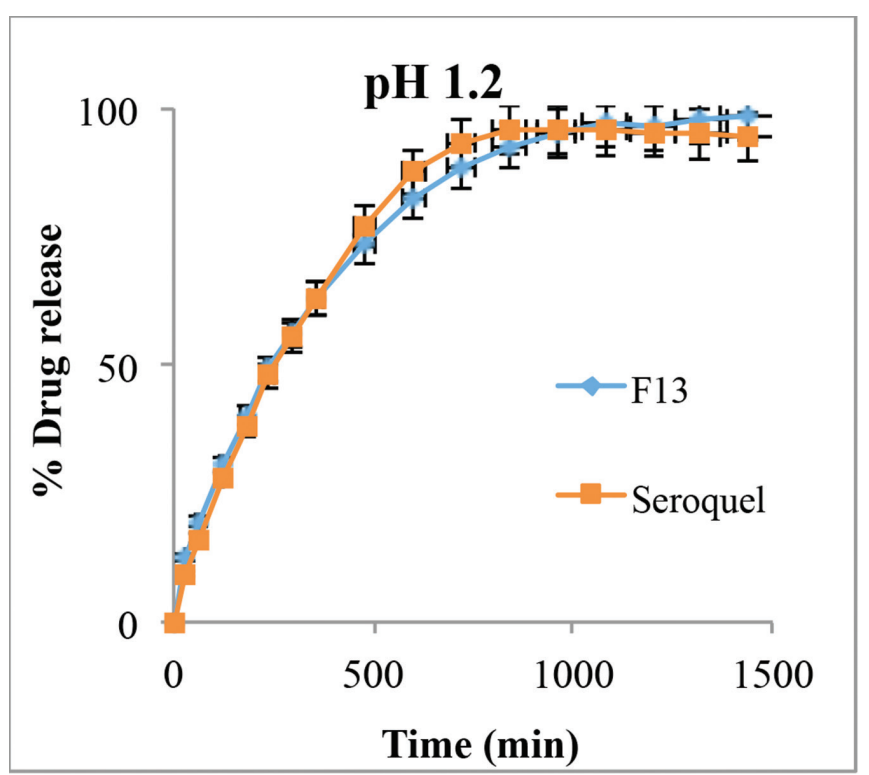

Figure 5. Dissolution profiles of $\mathrm{F} 13$ and reference product at $\mathrm{pH} 1.2(\mathrm{n}=6)$

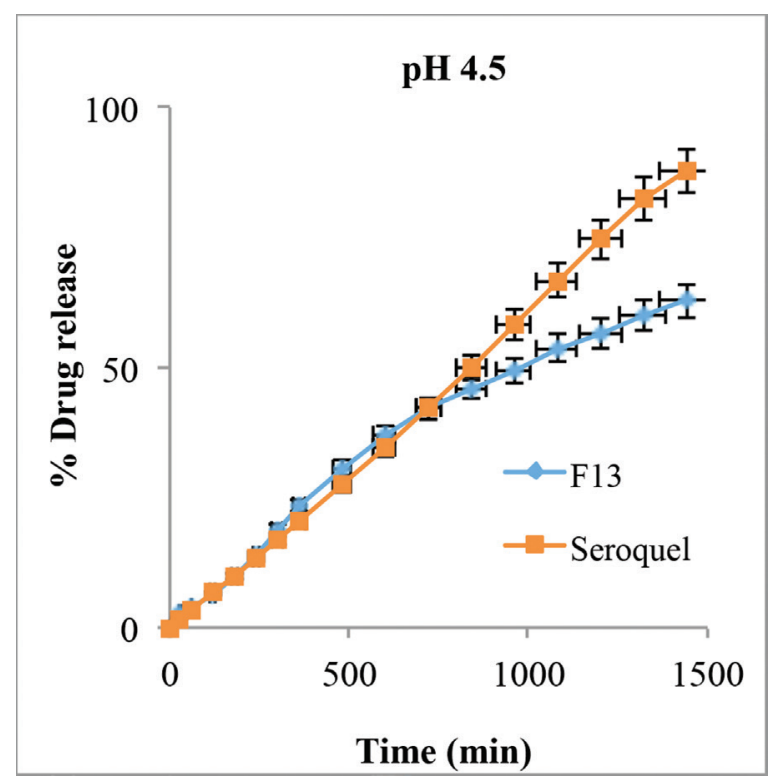

Figure 6. Dissolution profiles of $F 13$ and reference product at $\mathrm{pH} 4.5(\mathrm{n}=6)$

release studies. However, tablets with required performances were obtained in a shorter time with fewer trials due to the optimized formula suggestion of the INForm programs.

Similar programs have been used for the controlled-release formulation of clopidogrel using a matrix agent (Methocel $\mathrm{K}(00 \mathrm{M}){ }^{38}$ In another study, the formulation components (diluent, binder, and their concentrations) and operation variables (type of the granulator and addition of the binder) of caffeine were evaluated and optimized formulas were obtained. ${ }^{39}$ In addition, the controlled-release tablets of theophylline were developed using a study of simultaneous optimization technique. ${ }^{40}$ All these studies indicated that these programs performed better estimation than those of current statistical methods.

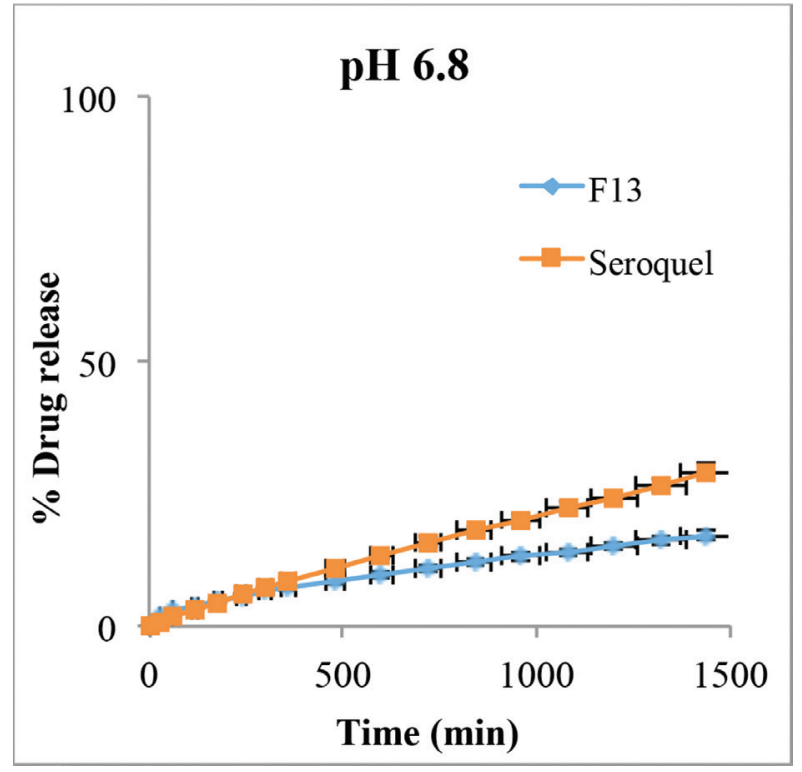

Figure 7. Dissolution profiles of F13 and reference product at $\mathrm{pH} 6.8(\mathrm{n}=6)$

It also should be kept in mind that these programs have some disadvantages. The most important is that models can be over-trained. In that case, the value of $r^{2}$ might reach 0.95 or higher, and the background color turns to red. In such a case, model parameters are needed to be reviewed, checked, and retrained.

In our study, a release tablet formulation of quetiapine fumarate using a different polymer than that of its marketed product was optimized with lower cost and fewer trials, and in a shorter time by using ANN programs.

\section{CONCLUSION}

The greatest benefit of the FormRules program was understandable models, impressive experimental results and clearly described mathematical concept data. The program generated a rule base and contained all observations, experiences, and mathematical connections related to the subject, i.e., all information. The better and broader the rule base was prepared, the more precise and correct results were obtained. It presented data visually as three-dimensional graphs, which allowed us to extract the information quickly and easily, therefore enabling us to see which input was really effective on our formulation and also facilitating our decisions on how to obtain the most efficient results.

Using these programs, we attained information that tablets composed of xanthan gum were more successful than those that consisted of Carbopol 974P in extending the release of quetiapine fumarate from an ER tablet formulation. We evaluated the parameters including polymer concentration and mesh size of granules. A genetic algorithm-based optimization was performed and an optimized formula similar to the reference product was recommended. Without genetic algorithmbased optimization, more formulation trials would have been necessary to obtain the optimum formula. Consequently, it 
has been shown that an ER tablet formulation of quetiapine fumarate could be optimized quickly and at a lower cost.

\section{ACKNOWLEDGEMENTS}

This study was supported by Research Fund of the İstanbul University project number: 26586. An application for a patent has been made to the Turkish Patent Institute using the results of this study (Application number: TR 2013-G-316804).

Conflict of Interest: No conflict of interest was declared by the authors.

\section{REFERENCES}

1. Gawali P, Gupta A, Kachare S, Kshirsagar S. Formulation and evaluation of matrix-based sustained release tablets of Quetiapine fumarate and the influence of excipients on drug release. J Chem Pharm Res. 2012;4:3073-3081.

2. Völgyi G, Baka E, Box KJ, Comer JE, Takács-Novák K. Study of pHdependent solubility of organic bases. Revisit of Henderson-Hasselbalch relationship. Anal Chim Acta. 2010;673:40-46.

3. Pasha MK, Velrajan G, Balasubramaniam V, Dayakar B, Shivakumar B. Formulation and evaluation of extended release matrix tablets of quetiapine fumarate tablets. Int J Pharm. 2013;3:14-19.

4. Hiremath PS, Saha RN. Controlled release hydrophilic matrix tablet formulations of isoniazid: design and in vitro studies. AAPS PharmSciTech. 2008;9:1171-1178.

5. Wen H, Park K. Oral controlled release formulation design and drug delivery: Theory and Practice. In: Wen H, Park K. New Jersey, USA; Wiley; 2010. pp. 8.

6. García-Ochoa F, Santos VE, Casas JA, Gómez E. Xanthan gum: production, recovery, and properties. Biotechnol Adv. 2000;18:549-579.

7. Peh KK, Wong CF. Application of similarity factor in development of controlled-release diltiazem tablet. Drug Dev Ind Pharm. 2000;26:723730.

8. Kristensen HG, Schaefer T. Granulation: A review on pharmaceutical wet granulation. Drug Dev Ind Pharm. 1987;13:803-872.

9. Mandal U, Gowda V, Ghosh A, Bose A, Bhaumik U, Chatterjee B, Pal TK. Optimization of metformin $\mathrm{HCl} 500 \mathrm{mg}$ sustained release matrix tablets using Artificial Neural Network (ANN) based on Multilayer Perceptrons (MLP) model. Chem Pharm Bull. 2008;56:150-155.

10. Aksu B. Innovative pharmaceutical manufacturing practices in Ramipril tablet manufacturing process, Doctorate Thesis, pp. 34, Department of Pharmaceutical Technology, Ege University of Izmir, 2010.

11. Golla S, Neely BJ, Whitebay E, Madihally S, Robinson RL Jr, Gasem KA. Virtual design of chemical penetration enhancers for transdermal drug delivery. Chem Biol Drug Des. 2012;79:478-487.

12. Almeida JS. Predictive non-linear modeling of complex data by artificial neural networks. Curr Opin Biotechnol. 2002;13:72-76.

13. Peh KK, Lim CP, Quek SS, Khoh KH. Use of artificial neural networks to predict drug dissolution profiles and evaluation of network performance using similarity factor. Pharm Res. 2000;17:1384-1388.

14. Mesut B, Aksu B, Ozsoy Y. Design of Sustained Release Tablet Formulations of Alfuzosin $\mathrm{HCl}$ by means of Neuro-Fuzzy Logic. Lat Am J Pharm. 2013;32:1288-1297.
15. Intelligensys Ltd. UK, 2009. Available from http://www.intelligensys. co.uk/

16. Dematas $M$, Shao $Q$, Shukla R. Artificial intelligence the key to process understanding. Pharm Tech Eur. 2007;19:44-49.

17. Colbourn E, Rowe CR. Neural Computing and Formulation Optimization. Encyclopedia of Pharmaceutical Technology. In: Swarbrick J. New York; Informa Healthcare; 2007. pp. 2399-2412.

18. Aksu B, De Matas M, Cevher E, Özsoy Y, Güneri T, York P. Quality by design approach for tablet formulations containing spray coated ramipril by using artificial intelligence techniques. Int J Drug Delivery. 2012;4:5969.

19. Wu H, Khan MA, Hussain AS. On-line process control and process analytical technology: integration of chemical engineering practice into semiconductor and pharmaceutical industries. Chem Eng Commun. 2007;194:760-779.

20. Yu LX. Pharmaceutical quality by design: product and process development, understanding, and control. Pharm Res. 2008;25:781-791.

21. Verma S, Lan Y, Gokhale R, Burgess DJ. Quality by design approach to understand the process of nanosuspension preparation. Int J Pharm. 2009;377:185-198.

22. Aksu B, Paradkar A, de Matas M, Özer Ö, Güneri T, York P. A quality by design approach using artificial intelligence techniques to control the critical quality attributes of ramipril tablets manufactured by wet granulation. Pharm Dev Technol. 2013;18:236-245.

23. Aksu B, Paradkar A, de Matas M, Ozer O, Güneri T, York P. Quality by design approach: application of artificial intelligence techniques of tablets manufactured by direct compression. AAPS PharmSciTech. 2012;13:1138-1146.

24. ICH Q6A Specifications: Test Procedures and Acceptance Criteria for New Drug Substances and New Drug Products: Chemical Substances. Available from www.ich.org. Accessed January 24, 2008.

25. Uddin MS, Al Mamun A, Tasnu T, Asaduzzaman M. In-process and finished products quality control tests for pharmaceutical tablets according to pharmacopoeias. J Chem Pharm Res. 2015;7:180-185.

26. Bharathi Ch, Prabahar KJ, Prasad ChS, Srinivasa Rao M, Trinadhachary GN, Handa VK, Dandala R, Naidu A. Identification, isolation, synthesis and characterization of impurities of quetiapine fumarate. Pharmazie 2008;63:14-19.

27. International Conference on Harmonization of Technical Requirements for Registration of Pharmaceutical for Human Use, Validation of Analytical Procedures: Methodology, Q2 (1995).

28. Draft guidance on quetiapine fumarate, Recommended July 2008, FDA. Available from http://www.fda.gov/downloads/Drugs/.../Guidances/ UCM089520.pdf, Accessed: July 2009.

29. Guidance for Industry, Dissolution Testing of Immediate Release Solid Oral Dosage Forms, U.S. Department of Health and Human Services, Food and Drug Administration (FDA), Center for Drug Evaluation and Research (CDER), August 1997, pp.8. Available from http://www.fda. gov/downloads/drugs/guidancecomplianceregulatoryinformation/ guidances/ucm070237.pdf f2.

30. Shao Q, Rowe RC, York P. Investigation of an artificial intelligence technology Model trees. Novel applications for an immediate release tablet formulation database. Eur J Pharm Sci. 2007;31:137-144.

31. Tablet friability, Final text for addition to The International Pharmacopoeia, World Health Organization, Document QAS/11.414 FINAL March 
2012. Available from: http://www.who.int/medicines/publications/ pharmacopoeia/TabletFriability_QAS11-414_FINAL_MODIFIED_ March2012.pdf.

32. United States Pharmacopoeia Convention. United States Pharmacopoeia 38-National Formulary 33. USA; Stationery Office; 2010.

33. Soppela I, Airaksinen S, Hatara J, Räikkönen H, Antikainen O, Yliruusi J, Sandler N. Rapid particle size measurement using 3D surface imaging. AAPS PharmSciTech. 2011;12:476-484.

34. Kanwar N, Kumar R, Sarwal A, Sinha VR. Preparation and evaluation of floating tablets of pregabalin. Drug Dev Ind Pharm. 2016;42:654-660.

35. Pandey S, Shah RR, Gupta A, Arul B. Design and Evaluation of buccoadhezive controlled release formulations of prochlorperazine maleate. Int J Pharm Pharm Sci. 2016;8:375-379.
36. Körner A, Piculell L, Iselau F, Wittgren B, Larsson A. Influence of different polymer types on the overall release mechanism in hydrophilic matrix tablets. Molecules. 2009;14:2699-2716.

37. Fu XC, Wang GP, Liang WQ, Chow MS. Prediction of drug release from HPMC matrices: effect of physicochemical properties of drug and polymer concentration. J Control Release. 2004;95:209-216.

38. Tan C, Degim IT. Development of sustained release formulation of an antithrombotic drug and application of Fuzzy logic. Pharm Dev Technol. 2012;17:242-250.

39. Kesevan JG, Peck GE. Pharmaceutical granulation and tablet formulation using neural networks. Pharm Dev Technol. 1996;1:391-404.

40. Takayama K, Morva A, Fujikawa M, Hattori Y, Obata Y, Nagai T, Formula optimization of theophylline controlled release tablet based on artificial neural networks, J Control Release. 2000;6:175-186. 